МАША ВУКАНОВИЋ

Завод за проучавање културног развитка, Београд

DOI 10.5937/kultura1651227V

УДК 930.85(497.11)

711.4(497.11)"19"

338.48:008(497.11)

прегледни рад

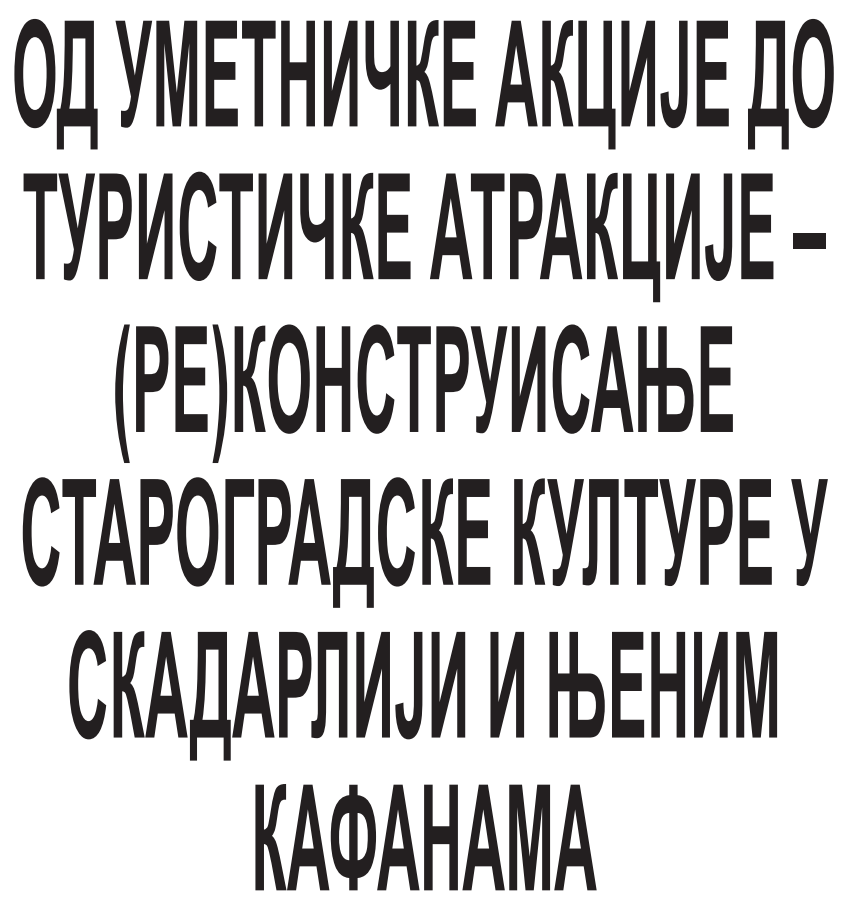

Сажетак: Београдске градске власти су се још 1920-их определиле да се (Бео)град представља наглашавањем његове историје, културе и квалитетног друштвеног живота. Друштвени живот престонице пре свега се одвијао у кафанама, а међу кафанским „епичентрима“ је од краја 19. века четврт Скадарлија. Она и данас сведочи о (старо)градском духу. Представљајући укратко историјат Скадарлије, уметничку акцију којом је ова четврт крајем '60-их година 20. века оживела и туристичку атракцију савременог Београда, рад је посвећен питану кониептуализаиије Београда као града игре.

Кључне речи: Скадарлија, кафане, боеми, уметничка акиија, туристичка атракиија, град игре 


\section{Увод}

Изградња кафана у Београду први пут је регулисана Уредбом о механама која је обнародована 1861. године. У додатку ове Уредбе објављеном 1864. године кафане су дефинисане као „зграде где се јавно крчми кафа и свако јело и пиће даје”. Према попису из 1921. године у Београду је живело 111.739 становника а 1930. године у њему су биле регистроване 3.622 кафане и механе 2 . Почетком 21. века велики број кафана је или затворен или реновиран у складу са новом модом кафића - ресторана. Ипак, у Београду постоји простор у коме је, углавном у непромењеном облику, очувано неколико старих кафана. Тај простор је Скадарлија.

До средине 19. века у безименим сокацима и скромним кућерцима данашње Скадарлије живели су Роми те је четврт била позната под називом „Циган махала”. Ово насеље почиње да ишчезава пред крај 19. века уступајући места солиднијим грађевинама као што је и данас постојећа зграда на броју 31 највеће од блатњавих улица која је 1872 . године добила име Скадарска улица. Касније, у Скадарлији су живели познати уметници: Ђура Јакшић (Скадарска бр. 34), Чича Илија Станојевић (такође у кући у којој је живео Ђура Јакшић, Скадарска бр. 34), Милорад Гавриловић (у кући Козланског, преко пута кафане „Два јелена”), Димитрије Гинић (Скадарска бр. 34), Жанка Стокић (Скадарска 27), Добрица Милутиновић (Зетска бр. 2) и др. ${ }^{3}$ Већи део својих дана и ноћи ови уметници су проводили у кафанама, нарочито у онима у комшилуку.

При дну Скадарске улице је још средином 19. века, око 1850. године, почео да се формира индустријски комплекс пиваре чији је власник најпре био Филип Ђорђевић а потом Бајлони. Захваљујући механи пиваре, „уз занатске радње, пиљарнице, пекаре, фабрику шешира и друге продавнице, у Скадарлији се јављају грађевине угоститељске намене. (...) Највероватније током седме или осме деценије у Зетској број 2 отворена је кафана 'Бумс Келер' будући да се улица истог назива помиње 1876. године. Следе кафане 'Вук Караџић' у Скадарској број 3, 'Златни бокал' на броју 16 (...) 'Милош Обилић' и 'Бандист', те свакако најгласовитија кафана

1 Ђурић - Замоло, Д. (1988) Хотели и кафане ХІХ века у Београду, Београд: Музеј града Београда стр. 171.

2 Голубовић, В. (2005) Кафане старог Београда, Београд: ЦД група стр. $41,43$.

3 Видети: Dimitrijević, K. (1983) Skadarlija, Beograd: Jugoslavija Publik i SIZ „Skadarlija”. 


\section{МАША ВУКАНОВИЋ}

- 'Три шешира', смештена у приземници некадашњег скадарлијског шеширџије Димовића."4

Кафане се најједноставније могу одредити као (наткровљен) простор са столовима и столицама у коме се служе храна и пиће. Кафане као места за сести, појести и попити су, пак, „примарни ниво кафанске културне феноменологије”. Нушић је забележио да се сав друштвени живот одвијао у кафанама:

„Што се више развијала нова престоница, кафане су све више и више постајале центри у којима се кретао живот. Ту се састајали људи ради споразума; ту заказивали састанке ради посла, ту су се чак и адвокати консултовали са клијентелом, ту се заказивао састанак између проводаџије и девојачког оца, ту је дужник потписивао меницу, ортак уговор, тужилац пуномоћје, и готово сви јавни акти, изузимајући тестамента, обављали су се у кафани. Ту су друштва држала састанке; ту политичари склапали завере и конспирације, ту је често и болесник потражио доктора да га припита за савет."”

Кафане су биле и својеврсне учионице књижевности и језика. Присећајући се дана у кафани „Три шешира” прослављени глумац Добрица Милутиновић каже да је слушање књижевника попут Јанка Веселиновића, Милована Глишића и Бранислава Нушића док разговарају у кафани пружало лекције у којима се истицала лепота и богатство српског језика. ${ }^{7}$

Разговорима у (скадарлијским) кафанама штимунг је стварала музика коју су изводили стално ангажовани оркестри, нарочито тамбурашки и хармоникашки. ${ }^{8}$ На репертоару су биле сокачке и бећарске песме (на пример: „Хитнуо сам удицу”, „Крчмарице, поређај столице”, „Идем ја, иде калдрма”, „На крај села чађава ме’ана”, итд), серенаде (на пример

4 Богуновић, С. (2005) Архитектонска енциклопедија Београда ХІХ и ХХ века, Београд: Београдска књига, стр. 363.

5 Тирнанић, Б. (1983) Београд за почетнике - Бедекер кроз носталгију, Београд: Нолит, Библиотека Грифон, стр. 77.

6 Нушић, Б. (2005) Београдске кафане, у: Стари Београд - путописи из ХІХ века, Београд: ЗД+, стр. 176.

7 Димитријевић, К. (1986) Седам прича о белом граду, Горњи Милановац: Дечје новине, стр. 57.

8 Посебно популарни су били оркестар „Тамбурица пет” и „Скадарлијски добошар”. Међу познатим певачима који су наступали у скадарлијским кафанама били су Тома Здравковић, Љиљана Петровић Бутлер, Софка која је наступала у кафани „Код два јелена” и други. 


\section{МАША ВУКАНОВИЋ}

„Тихо ноћи”), родољубиве (на пример „Тамо далеко”), локал-патриотске (на пример: „У тем Сомбору”, „Пољупце је чак из Лувра слала Шапцу Мона Лиза”, итд), севдалинке (на пример: „Мила мајко шаљи ме на воду”, „Ударало момче у тамбуру”, „Снијег пада на бехар на воће”, „Вино пију аге Сарајлије”, итд), као и песме из позоришних представа. Некадашњи директор Народног позоришта г. Јован Ђорђевић је рекао „да је свака песма отпевана у позоришту за час постајала - народном песмом." И дан данас међу популарнијим староградским песмама су „Ој леле, леле” из представе „Сеоски лола” 10 и „Хајде Като, хајде душо” која је била хит песма представе Чича Илије Станојевића „Дорћолска посла".

У песми би се певачима и оркестрима често придружили и гости, о чему сведочи и сећање глумца Добрице Милутиновића: „Јанко [Веселиновић] са гуслама... Како је он певао уз гусле, сине... Никада нисам чуо бољег. И једног дана певао је тако уз гусле, у препуној кафани... Пева Јанко, а свет се претворио у уво, тишина, све стало... Сви знају: то Јанко гусла."11

Атмосфера из кафана се преносила и на улице чинивши Скадарлију посебним амбијентом у Београду. Стојков је амбијент дефинисао као „простор или комплекс у насељу у коме доминирају (или га одређују) елементи значајни за колективну меморију, односно за естетски, духовни или емотивни доживљај већине становника насеља (посебно домородачког), те због тога има карактер јавног интереса."12 Захваљујући уметничкој акцији из 60-их година 20. века Скадарлија је и данас важан београдски амбијент у коме живи конструкт старе (бео)градске културе и некадашњег духа града.

9 Перић, Ђ. (1995) Позоришне песме у записима српских мелографа XIX века (Прилог испитивању позоришног порекла староградске поезије српских песника), Српска музичка сцена, Београд: Музиколошки институт САНУ, стр. 153.

10 Ову песму је написао Драгомир Брзак а Јосиф Маринковић ју је у II коло српских народних песама уврстио као народну. За њу је Лаза Костић рекао „да би морала растопити и најозеблије срце”. Видети: Лесковац, М. Позоришне критике Лазе Костића, у: О Лази Костићу, (1978) Београд, стр. 155-156; цитирано из Перић, Ђ. нав. дело, стр. 149.

11 Димитријевић, К. нав. дело, стр. 63.

12 Стојков, Б. (1997) Амбијент као тема обнове Београда, Наслеђе год. 1, бр. 1, Београд: Завод за заштиту споменика културе града Београда, стр. 159. 


\section{МАША ВУКАНОВИЋ}

\section{Уметничка акција}

Важност Скадарлије као амбијента први пут је истакнута у Уредби о заштити београдских старина из 1935. године. У њој стоји да се овај део града „мора сачувати у постојећем стању и на којем се не могу вршити никакве промене без дозволе надлежне власти“ те да се на куће у којима су живели познати уметници ставе табле. ${ }^{13}$ И заиста, наредних деценија нису вршене промене, али није било ни значајнијих подухвата у погледу одржавања те је четврт почела да поприма обележја оронулости.

Дружећи се и практично живећи у таквом амбијенту уметници који су се етаблирали или пробијали крајем 50-их и почетком 60-их година покренули су иницијативу за ревитализацију Скадарлије. Архитекта Угљеша Богуновић је 1957. године у листу „Политика” објавио текст у коме је изнео своја размишљања о Скадарлији, као и идеју да се овај део града ревитализује. По објављивању овог текста уметници, новинари и стални гости скадарлијских кафана су почели са пописивањем значајних имена српске и југословенске културе који су у скадарлијским кафанама стварали своја дела ${ }^{14}$ и уметничке клубове, као и друга остварења за будуће нараштаје $^{15}$. У петицијама и молбама је указивањем на места (нарочито кафане) у којима су живели и дружили се уметници наглашавана аутентичност амбијента. Најзад, али и захваљујући сплету историјских околности (о којима ће више речи бити мало касније), средином 60-их година молбе и петиције су уродиле плодом. У Градској скупштини Београда је 17. маја 1966. године одржан састанак коме су присуствовали представници градских власти, архитекта Угљеша Богуновић, сликар и књижевник Зуко Џумхур и сликар Марио Маскарели, као представници уметника који су покренули

13 Уредба о заштити београдских старина, „Београдске општинске новине" (БОН), број 1, јануар 1936, стр. 91. Спомен плоча је постављена само на кући у којој је живео Ђура Јакшић а њено постављање је финансирао тадашњи власник кафане „Три шешира“ газда Стојан Крстић.

14 Димитријевић у монографији Скадарлија наводи да је Ђура Јакшић готово целу своју драму „Станоје Главаш“ написао у кафани „Златни бокал”. Такође, Димитријевић пише: „Испијајући своју обавезну ракију код „Три шешира”, врсни приповедач Стеван Сремац, кажу, није се одвајао од своје бележнице, записујући дијалоге које је ту чуо и касније преносио у своја дела.” У кафани „Три шешира” инспирацију је налазио и Бранислав Нушић а у истој кафани је и Антун Густав Матош написао велики број својих дописа и памфлета. Видети: Dimitrijević, K. (1983) Skadarlija, Beograd: Jugoslavija Publik i SIZ „Skadarlija”

15 Међу честим гостима кафане „Три шешира” била су и браћа Рибникар те је управо у овој кафани 25. јануара 1904. године прослављен излазак из штампе првог броја листа „Политика”. 
идеју ревитализације Скадарлије, те Богољуб Старчевић, тадашњи председник Туристичког савеза Београда који је и предузео кораке да се у оквиру „Београдског лета” у Скадарлији почну одвијати уметнички програми. На том састанку је договорено да пројекат ревитализације уобличи иницијатор идеје Угљеша Богуновић, који је до тада углед стекао пројектима зграде „Политике” и торњева на Авали и Иришком венцу.

Припремајући планове и пре него што су градске власти одобриле пројекат ревитализације Богуновић је на уму имао да Скадарлија сведочи о турском добу и оријенталним утицајима. Она је, по Богуновићу, контраст растућем модерном граду и то баш у његовом најстрожем центру, те је и у својим плановима настојао да потцрта ову својеврсну урбанистичку сепарацију. Сматрајући да Скадарлија спаја „старобалканску духовност и европски модернизам" али и демонстрира отпор друштвеној отуђености која је надирала са убрзавањем и променама велеградског живота, планови Богуновића су укључивали и позориште, галерије, мале етно просторе итд, како би Скадарлија била јединствени културни простор који приказује бурни, слободарски, дух града. ${ }^{16}$ Реализација Богуновићевог пројекта почела је 1967. године. У односу на планове, обновљен је део Три шешира, анекс Два јелена и кућа Ђуре Јакшића. Враћањем чесме ${ }^{17}$ укинут је колски саобраћај, промењена је калдрма а осветљење регулисано фењерима и канделабрима. Када је 1972. године постављена чесма, радови су прекинути.

Ревитализација је обухватила и унутрашњост скадарлијских кафана. Уређење ентеријера започео је сликар и писац Зуко Џумхур направивши „инсталацију” од чокањчића у кафани „Три Шешира”. У уређењу ентеријера других кафана, као што су „Има дана”, „Златни бокал” и „Код два бела голуба”, учествовали су Угљеша Богуновић, Милица Рибникар, Момо Капор, Марио Маскарели, Соја Јовановић, Александар Ђорђевић, Душан Антонијевић, Ђорђе Караклајић и др.

Не заборављајући да су кафане места где се служи храна, пажња је посвећена и јеловницима. Према Рајчевићу, у обновљеним кафанама јеловнике, базиране на народним јелима, сачинила је професорка са Одељења за етнологију и антропологију Филозофског факултета у Београду, др

16 Серијал: Модерна архитектура Србије - Личности и поетика, Емисија Укрштај различитих светова - архитекта Угљеша Богуновић; Приказано 1. 12. 2003. године на 2. програму Радио-телевизије Србије.

17 Чесма је поклон града Сарајева, а њена ауторка је уметница Милица Рибникар. 
Сребрица Кнежевић, која се бавила проучавањима традиционалне гастрономије. ${ }^{18}$

Борка Павићевић је покренула позориште. „У кабареу Џивџан, сцени на пивским бурићима, игра се комад у коме глумци Народног позоришта евоцирају успомене на скадарлијску боемију, причају се и препричавају анегдоте о Чича Илији Станојевићу, о Матошу, о Драинцу. Са прозора куће Ђуре Јакшића, тада још увек приватног стана, већ се говори поезија Ђурина, Трифунова, Крклецова, Живојиновићева..."19 Инспирисани атмосфером, генерације песника су опевале амбијент Скадарлије, на пример Растко Петровић, Густав Крклец, Бранко В. Радичевић, Добрила Николић, Добрица Ерић, Љубивоје Ршумовић и др. Песме инспирисане Скадарлијом, а написане перима књижевника разних генерација, прикупио је и, у збирци поезије Скадарлија наш Монмартр, објавио историчар уметности Угљеша Рајчевић. Отворена је галерија - антикварница. Уметничка дела, слике и графике су излагали и продавали уметници попут Милића од Мачве, Марија Маскарелија, Данице Антић, Ксеније Дивјак и др. Неко кратко време постојала је дискотека „Монокл“а а Скадарлија је била корзо.

Ефекти спроведених акција одјекнули су у Урбанистичком пројекту Скадарлије усвојеном 1981. године. У овом документу наведене су следеће вредности Скадарлије:

- Као архитектонско - урбанистичка целина специфичног ликовног садржаја и спонтано настали живописни скуп објеката бивше периферије;

- Као део старог језгра града;

- Као место живог мита о београдској боемији;

- Као амбијентална целина посебне градске атмосфере остварене једноставном градњом, зеленилом и погодном локацијом, као и свакодневним догађањем. Целина има низ најстаријих београдских кафана и стамбених зграда где су се сакупљали и живели познати писци, сликари, глумци, млађи свет, а и остали. Подизана у разним етапама развоја Београда, представља својеврстан урбанистички склоп спонтаног грађења;

18 Серијал Скадарлија. Уводна емисија емитована 30. 05. 2008. године на 2. програму Радио-телевизије Србије

19 Рајчевић, У. (1994) Скадарлија наш Монмартр. Сабране песме, Београд: Доситеј, стр. 8. 
- Карактеристична је слободна траса улице која је пратила део правца београдског шанца са његове спољне стране и после много рушења града, кроз његову бурну историју, остала непромењена;

- Као туристичка атракција представља се свакодневном посетом и до 10000 гостију, углавном младих. Тако је значајна и као туристичка понуда савременог тренутка;

- Као део културног центра града са позоришним сценама (специфичног карактера) организованим на улици, у баштама или угоститељским објектима, са разним изложбама слика, цвећа, старина, књига и слично;

- Као популарно место за састанке грађана, њихов одмор и забаву;

- Као део старог градског језгра представља се и близином осталих историјских објеката и амбијената у ближем и даљем суседству, па са њима чини интересантан и споменички ланац;

- Као кулинарски центар старог Београда;

- Постојањем слободног простора за ширење (близина Мале пиваре, тзв. Бајлонијеве пиваре);

- И на крају, као реална могућност продужавања, оплемењивања, свих својих позитивних карактеристика које су провером доказане, без обзира да ли су правовремено пројектоване или су се у току реализације саме искристалисале."20

На основу овако побројаних вредности Скадарлије отпочео је њен пут ка туристичкој атракцији.

\section{Туристичка атракција}

Захваљујући кафанама које су обликовале амбијент и уметничким акцијама које су простор оживеле, Скадарлија је репрезентовала дух града. То су у виду имале и службе протокола па је Скадарлију и кафане у њој посетио велики број значајних личности светске политичке и уметничке сцене. Према наводима са Интернет презентације кафане „Два јелена" у неколико наврата гост ове кафане био је југословенски председник Јосип Броз Тито, као и (некадашња) британска премијерка госпођа Маргарет Тачер и некадашњи

20 Цитирано из: Димитријевић, К. нав. дело. 
председник САД Џими Картер 21 , док су у другим скадарлијским кафанама међу угледним гостима из света политике били венецуелански председник Перез, Џорџ Буш Старији (додуше не као председник САД већ као високи функционер у администрацији председника), и др. Из света уметности и науке, међу гостима скадарлијских кафана били су глумци Елизабет Тејлор, Ричард Бартон, Катрин Денев, Роберт де Ниро, редитељи Паоло Мађели, Питер Брук, Бернардо Бертолучи, филозоф Роман Ингарден, и многи други. После познатих личности у скадарлијске кафане су у све већем броју почели да долазе туристи.

Препознајући туристичке потенцијале Скадарлије (о чему сведочи и поменути Урбанистички пројекат Скадарлије), градске власти су од остварених боравишних такси издвајале средства за одржавање објеката, те подржавале подухвате Туристичког савеза, (данас Туристичке организације Београда), у осмишљавању садржаја намењених и гостима Београда али и самим Београђанима. Посебно се истицала манифестација „Скадарлијске вечери”.

Међутим, они који чине дух града постепено су истискивани из Скадарлије: „Скадарлија, нова, туристичка, подигнута на легенди и даровима скадарлијске боемије, иако то нико није ни желео ни очекивао, одгурнула је од себе управо те којима је највише дуговала. Нови програмски концепт Скадарлијских вечери, умивене кафане и амбициозни управници ресторана (до јуче кафана) чували су у својим локалима места само за пробране и пробирљиве госте, за оне који ће из шарених јеловника поручити скупа јела и пића, специјалитете куће, а не само хладну 'шљиву', пресечено бело и папке у сафту (евентуално). За наше песнике, за ноћобдије, у Скадарлији је, отад, било све мање места."22

Пред крај 2015. године, спремни за дочек нове 2016., представници Туристичке организације Београда и скадарлијских ресторана су у „Јутарњем програму” РТС-а ${ }^{23}$ истакли да се „као и претходних година” пре свега очекују инострани гости нарочито из бивших југословенских република. У углавном од 70-их година непромењеном екстеријеру ${ }^{24}$ и незнатно модернизованом ентеријеру, на понуди су домаћи гастрономски специјалитети и музички програм коме су

21 Видети http://www.dvajelena.rs/ Страница посећена 21. 12. 2015.

22 Рајчевић, У. нав. дело, стр. 8-9.

23 Прилог је емитован 17. 12. 2015. године у „Јутарњем програму” 1. програма Радио-телевизије Србије.

24 Изузетак чини '80-их година подигнут тржни центар на месту кућа међу којима је била и она у којој је била смештена дискотека „Монокл”. 
поред некадашњих староградских хитова придодате и новије песме попут Бајагине „Моји су другови” или Легенди „Нема старог Београда” итд.

Почетком 21. века у Београду постављена нова туристичка сигнализација усмерава ка Скадарлији - боемској четврти (енг. Skadarlija - bohemian quarter). Антун Густав Матош је приметио да је историја наше књижевности заправо историја наше боеме. Описујући боеме - госте београдских (и скадарлијских) кафана Нушић каже: „То су били ведри, весели и духовити људи који су претпостављали 'друштво' свакој другој дужности у животу."25 Овај Нушићев опис сажима бројне експликације суштине боемије и боема ${ }^{26}$ а на основу тога се може рећи да придев „боемска” уз именицу „четврт” сугерише простор, амбијент у коме преовладава весела, необавезујућа и готово раскалашна атмосфера, што кореспондира са представом Београда као града игре.

\section{Град игре}

Разматрајући питања глобализације у контексту развоја градова Шорт и Ким су истакли две главне теме у маркетингу градова, односно два концепта који се користе у позиционирању градова на домаћој и међународној „сцени”: град рада у коме се економски развој остварује привлачењем компанија и корпорација да управо у том граду базирају своје пословне активности за тај део света; и град игре у коме се наглашавају историја, култура и квалитет друштвеног живота, а економски развој се остварује првенствено кроз туризам и сектор услуга. ${ }^{27}$ Прожимањем идеја прогреса, културе, особених прилика живота и рада, концепти града рада и града игре се све чешће додирују и преплићу. ${ }^{28}$

Опција позиционирања Београда пре свега као града игре може се пратити током деценија. Њено идентификовање и

25 Нушић, Б. (1935) Из полупрошлости, Београд: Издавачко предузеће Геца Кон, стр. 233

26 Експликације боема и боемије детаљно су изнете на страници http:// www.mtholyoke.edu/courses/rschwart/hist255-s01/boheme/evolution.html Страница је посећена децембра 2015. године. Такође, о суштини боемије као начина живота писао је и Хамваш у есеју Филозофија вина. Видети: Хамваш, Б. (1947) Филозофија вина, у: Брига о животу, Сабрана дела Беле Хамваша, Београд: Геопоетика.

27 Short, J. R. and Kim, Y. H. (1999) Globalization and the City. New York: Addison Wesley Longman, p. 124

28 Такав је случај и у савременом Београду. На пример пројектом „Београд на води" тежиште се помера ка концепту града рада јер се пре свега предвиђа да ће комплекс бити привлачан будућим инвеститорима у привреду Србије. 
МАША ВУКАНОВИЋ

примењивање повезано је са историјским околностима у којима се град развијао.

Откако је 1867. године кнез Михаило пренео престоницу из Крагујевца у Београд, ,јадна селендра са уским, кривудавим и блатњавим улицама““29 почела је да израста у европску престоницу. Тада долази до функционалне преоријентације: претежно трговачки град на месту где се укрштају путеви са Истока ка Западу (и обрнуто) постаје интелектуални и административни центар. Оснива се Велика школа, из које је проистекао данашњи Универзитет у Београду, а чиновничка занимања постају све траженија.

Нови подстицај за развој града добијен је када је Београд постао престоница Краљевине Срба, Хрвата и Словенаца (потом Краљевине Југославије). Како би Београд био лепши и одговарао захтевима модерног града, Одбор општине града Београда је 17. маја 1921. године донео одлуку да се распише међународни стечај за израду плана уређења и проширења града. „За израду услова стечаја била је установљена нарочита комисија, која је била састављена од главних стручњака у земљи. У подацима за стечај истакнуто је да је Београд, као престоница, првенствено културно седиште, затим трговинско и најзад индустријско." ${ }^{30}$ Из обиља урбанистичких идеја садржаних у 17 планова који су приспели на стечај, руски емигрант архитекта Јурије Павлович Коваљевски, као главни аутор, уз помоћ две стручне групе за решење железничког чвора и пристаништа, сачинио је 1923. године Генерални урбанистички план. ${ }^{31}$ Иако власти Београдске општине нису поштовале многе елементе тога плана ${ }^{32}$, важно је истаћи да је њиме успостављен оквир за позиционирање Београда као града игре.

После Другог светског рата дошло је до промене друштвеног и политичког уређења Југославије, али је у представљању престонице нове државе опстао концепт града игре у

29 Црњански, М. (1999) Београд, Београд: Народна књига Алфа, стр. 20

30 Илић-Агапова, М. ([1933] 2002) Илустрована историја Београда, Београд: Дерета репринт, стр. 393, курзив додат.

31 Максимовић Б. (1981) Од студентских дана до трновитих стаза урбанизма Београда, у: Београд у сећањима, Београд: Српска књижевна задруга, стр. 51

32 Максимовић је међу недоследностима истакао да је уместо зграде Београдске општине изграђена Поштанска штедионица на углу Таковске и данас Булевара краља Александра; уместо зграде за просветне конференције - касарна краљеве гарде; на месту изгорелог „Мањеж” позоришта направљен је парк, док је здање новог позоришта, Југословенског драмског позоришта, мало померено у односу на оригиналну локацију. Видети: Максимовић, Б. нав. дело, стр. 53-55. 
коме је и седиште администрације. Истицање космополитског духа Београда, који се очитује кроз овај концепт, посебно је било важно у периоду самог краја 50-их када је СФР Југославија била изузетно активна у формирању Покрета

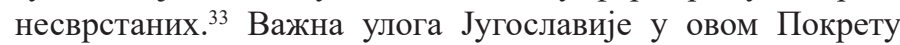
наглашавала је положај Београда на раскрсници Истока и Запада у географском, историјском, културолошком и политичком смислу појмова исток и запад. Управо је тај сплет историјских околности ишао на руку иницијативи за ревитализацију Скадарлије. Потврде настојања да се Београд представи као престоница државе отворене за нове идеје и тенденције пружају и крајем '60-их и почетком 70-их покренути Београдски интернационални театарски фестивал (БИТЕФ) ${ }^{34}$ и Београдски интернационални филмски фестивал ФЕСТ $^{35}$. Покрет несврстаних је Београд ставио на мапу светски значајних политичких центара, док су га БИТЕФ и ФЕСТ позиционирали у свету уметности и културе. Делимично ревитализована Скадарлија, с уметничким садржајима, који су дочаравали креативност Београђана и Југословена, и кафанама које су биле епицентри друштвеног живота, пружала је амбијент за неформалне сусрете.

Концепт града игре коришћен је и 1986. године када се Београд кандидовао за домаћина 25. летњих Олимпијских игара 1992. године. Организација олимпијских игара је један од начина да град оствари „међународну препознатљивост, психолошки пораст у вредности услед реклама и повећа пословне могућности развијајући тржиште некретнина и повећавајући инвестиције.” ${ }^{\prime 3}$. Промотивни спот уз, за ову прилику компоновану, песму Let's start the game - Belgrade is ready („Почнимо игру, Београд је спреман”) приказао је атракције Београда укључујући и Скадарлију истичући живописност града и полетност домаћина али то ипак није било довољно те је, са малом разликом у броју гласова, победу однела Барселона.

Космополитски и разигран дух града демонстриран је и током Студентског протеста 1996/'97. На почетку колоне студената који су свакодневно кретали у (повремено карневалске)

33 Прва конференција Покрета несврстаних који је окупио државе које се нису налазиле ни у западном ни у источном блоку одржана је управо у Београду 1961. године.

34 БИТЕФ је основан Решењем Скупштине града Београда од 26. децембра 1967. године а први фестивал је одржан наредне, 1968, године. У поднаслову фестивала стоји: „Нове позоришне тенденције”. Видети: http:/ festival.bitef.rs/o-festivalu/; Страница посећена 18. 12. 2015.

35 Први ФЕСТ је одржан 1971. године.

36 Short, J. R. and Kim, Y. Н. нав. дело, стр. 100. 
шетње по граду ношен је транспарент „Београд је свет“. Ова реченица је као мотив коришћена и на прослави „Дана Београда“" априла 2008. године, мада се превођењем на енглески језик изгубио део семантичке слојевитости. ${ }^{37}$

Иако још увек није био град домаћин летњих Олимпијских игара, Београд јесте био град домаћин летње Универзијаде 2009. године. Кроз пратеће програме учесницима и гостима је приближавана дуга историја и култура. Новобеоградски сплавови (за млађе) и скадарлијске кафане (за старије) гостима су пружали прилике да уживају у разиграном друштвеном животу. Међутим, од тада Скадарлија и њене кафане у животима грађана Београда имају све маргиналнију улогу. Акцентовање иностраних гостију на пример за новогодишње прославе те све мањи број Београђана који у Скадарлију не иду послом, макар „посао“ био да својим (приватним или пословним) гостима покажу остатке старог Београда, ову четврт чине резерватом некадашњих кафана у којима живи конструкт духа града који је ретко када разигран.

\section{Закључак}

Током скоро једног и по века махала у којој су живели Роми је прешла пут од блатњавих сокака до важног адута у туристичкој понуди Београда. Сместивши се између Стамбол - капије и Видин - капије, односно Дорћола и Палилуле, Скадарлија је била простор где су београдски боеми хтели да направе своју Боемску републику. Та хтења су дала и материјал за изградњу конструкта који сведочи о духу града. Дух града је апстракција која рефлектује колективну меморију и од значаја је за естетски, духовни и емотивни доживљају људи који у том граду живе (те донекле кореспондира са одредницом амбијента коју је дао Стојков), а при том се у овој апстракцији задржава динамичност стварања нових анегдота, урбаних легенди па и уметничких дела.

Подстрек динамици живота у Скадарлији дала је уметничка акција покренута крајем 50-их година и делимично спроведена крајем 60-их и на самом почетку '70-их. Она је полазила од разумевања Скадарлије пре свега као амбијента који упркос (тадашњим) околностима живи, а њен циљ је био да тај амбијент учини животнијим. У том смислу, акција је успела, али ипак је била релативно кратког даха. Већ 90-их година финансијска оскудица и високе цене у скадарлијским

37 Реч „свет” се може односити на пример на светињу или на свет у просторном и друштвеном смислу, појмове који на енглеском језику гласе holy (светиња) и world (свет). У сврхе манифестације „Дани Београда” одабрана је ова друга опција а међу плакатима се нашла и мапа Београда на којој су градске четврти уобличене исцртаним континентима. 
кафанама су утицале на то да се епицентри развоја духа града померају ван центра града и његових кафана - најпре у драгсторе ${ }^{38}$, а од бомбардовања 1999. године још више ка периферији града. Опадање кафанског живота и ефекте тога сажео је публициста Богдан Тирнанић: „Када говоримо о кафанској култури и о кафани као огледалу културе, тада, пре свега имамо на уму културу јела и пића, која, по нама, уопште није занемарљив проблем: ако опадање кафанског живота повежемо са чињеницом да се у нас све горе једе и да се перманентно сузбија конзумирање свих алкохолних пића осим чистих отрова, онда све то свакако није без везе са ситуацијом у којој се, рецимо, домаћа позоришта тешко одвајају од најприземнијег нивоа једне вулгарне експрес-самоуслуге јефтиних садржаја назови културе - лоша Српска кафана једнако је лош Атеље 212." 39

Могућност нове ревитализације Скадарлије, као четврти отворене и за Београђане и за госте Београда, крајем прве деценије 21. века истакнута је и у плановима везаним за приватизацију комплекса Бајлонијеве пиваре. Ти планови се у извесној мери наслањају на Богуновићеве идеје о Скадарлији али до њихове реализације (још увек) није дошло. ${ }^{40}$

Кроз историју скадарлијских кафана власници, потом и некадашње пословође (када је већина кафана прешла у друштвено власништво под управом угоститељског предузећа „Варош капија”), имали су разумевања за своје госте уметнике. Забележено је да је најпознатији власник кафане „Три шешира”, газда Стојан Крстић са својом супругом Наталијом веома ценио уметнике који су „боравили” у његовој кафани и до своје смрти, 1942. године, на различите начине их је помагао, док је његов „наследник” (пословођа чије име није забележено) неколико деценија касније је омогућио Џумхуру да направи инсталацију од чокањчића. Некада управници ресторана, данас менаџери, и даље се одазивају позивима Туристичке организације Београда да се укључе у програме попут подизања заставе на почетку летње сезоне,

38 Према личним сећањима током 1994. године испред драгстора у Зетској улици је било више људи него гостију у оближњим кафанама „Код два бела голуба” и „Два јелена” заједно.

39 Тирнанић, Б. нав. дело, стр. 77.

40 Нацрт плана реконструкције комплекса пивнице у дну Скадарске и у Цетињској улици те пасажа који би пивницу у Цетињској повезао са Скадарском улицом на нивоу тржног центра приказан је у тексту „Скадарлија 2010 - нови живот боемске четврти” објављеном 20. 02. 2008. године у дневним новинама „Политика”. На основу слике и објашњења, може се закључити да пројекат, осим што уместо позоришта и етно простора предвиђа нови ресторан, заправо не одудара значајно од Богуновићевих идеја. 
„Скадарлијских вечери”, сајмова рукотворина, итд. Ипак, годинама непромењена концепција програма ${ }^{41}$ углавном више не привлачи Београђане, за већину којих је и одлазак у скадарлијске кафане да би се у њима провело више времена од једног пића и евентуално помфрита или „пет с' луком” финансијски теже остварив подухват. При том, у јавним наступима представника Туристичке организације Београда и скадарлијских ресторана наглашава се да је Скадарлија Туристичка Атракција, дакле пре свега простор за туристе, што додатно од ње одбија оне који носе дух града јер се имплицитно сугерише да су позвани „про форме”. Више туриста у публици и све мање београдских „ноћобдија” као регуларних гостију, уз примену опробаних рецепата у конципирању програма чини да Скадарлија више личи на оклопљеног коњаника него на разиграног ата.

Ипак, од почетка 21. века Београђани су почели да се из драгстора враћају у кафане те је и улога ових „институција културе“" у развијању духа града је опет све значајнија без обзира на то како кафана изгледа и да ли се заиста зове кафана или се зове ресторан или кафић или кафе - ресторан. Уметничка акција ревитализације Савамале која се одиграла крајем прве деценије 21. века је, за сада последњи пример који говори да четврт расте захваљујући онима који су за њега везани више од краткотрајних лепих успомена, пример који је од краја 60-их до 90-их година 20. века пружала Скадарлија. Да ли ће се и у Скадарлији поново одиграти нека уметничка акција која ће ови четврт вратити на мапе пре свих Београђана остаје да се види.

\section{ЛИТЕРАТУРА:}

Богуновић, С. (2005) Архитектонска енциклопедија Београда ХIX и XX века, Београд: Београдска књига.

Голубовић, В. (2005) Кафане старог Београда Београд: ЦД група.

Dimitrijević, K. (1983) Skadarlija, Beograd: Jugoslavija Publik i SIZ „Skadarlija”.

\footnotetext{
41 У тексту „Стиже лето у Скадарлију” објављеном 06. 05. 2016. године у листу „Политика” најављено је да ће сутрадан, 7. маја, бити отворена нова летња туристичка сезона те да ће том приликом на платоу код чесме наступити полицијски оркестар, да ће добошар најавити „Кодекс о понашању у Скадарлији", да ће скадарлијску заставу подићи глумац Милорад Мандић Манда, да ће Скадарлијом шетати Скадарлијска дама Љиљана Јакшић а пролазнике поздрављати „Бранислав Нушић”, „Ђура Јакшић” и његова вољена „Мила”. Такође, „припремљен је и богат културноуметнички програм испред Куће Ђуре Јакшића. Причаће се анегдоте, певати познате староградске песме, а наступиће и КУД 'Талија'.' Упоредити са Рајчевић, У. нав. дело стр. 8-9.
} 


\section{МАША ВУКАНОВИЋ}

Димитријевић, К. (1986) Седам прича о белом граду, Горњи Милановац: Дечје новине.

Ђурић - Замоло, Д. (1988) Хотели и кафане ХІХ века у Београду, Београд: Музеј града Београда

Илић - Аргапова, М. (1933) Илустрована историја Београда, репринт Београд: Дерета.

Максимовић, Б. (1981) Од студентских дана до трновитих стаза урбанизма Београда, у: Београд у сећањима, Београд: Српска књижевна задруга.

Нушић, Б. (2005) Београдске кафане, у: Стари Београд - путописи из ХІХ века, Београд: 3 Д+.

Нушић, Б. (1935) Из полупрошлости, Београд: Издавачко предузеће Геца Кон А. Д.

Перић Ђ. (1995) Позоришне песме у записима српских мелографа XIX века (Прилог испитивању позоришног порекла староградске поезије српских песника), Српска музичка сиена, Београд: Музиколошки институт САНУ.

Рајчевић, У. (1994) Скадарлија наш Монмартр - Сабране песме, Београд: Доситеј.

Стојков, Б. (1997) Амбијент као тема обнове Београда, Наслеђе год. 1 бр. 1, Београд: Завод за заштиту споменика културе града Београда.

Short, J. R. and Kim, Y. H. (1999) Globalization and the City, New York: Addison Wesley Longman.

Тирнанић, Б. (1983) Београд за почетнике - Бедекер кроз носталгију, Београд: Нолит, Библиотека Грифон.

Црњански, М. (1999) Београд, Београд: Народна књига Алфа.

\section{Текстови из дневних новина:}

Аноним, (20. 02. 2008) „Скадарлија 2010 - нови живот боемске четврти", Политика, доступно путем линка http://www.politika. rs/scc/clanak/33570/Skadarlija-2010-novi-zivot-boemske-cetvrti; Страница посећена 23. 12. 2015.

Аноним, А. В. (06. 05. 2016.) „Стиже лето у Скадарлију”, Политика, доступно путем линка http://www.politika.rs/scc/clanak/354482/ Stize-leto-u-Skadarliju; Страница посећена 18. 05. 2016. 
МАША ВУКАНОВИЋ

Maša Vukanović

Center for Study in Cultural Development, Belgrade

\title{
FROM ARTISTIC ACTION TO TOURIST ATTRACTION - (RE)CONSTRUCTION OF THE OLD CITY CULTURE IN BELGRADE'S BOHEMIAN QUARTER SKADARLIJA AND ITS TAVERNS
}

\begin{abstract}
Since the early 1920s, the City of Belgrade authorities have adopted and cherished the marketing concept of a city at play - emphasizing the city history, culture and the quality of social life. The social life in Belgrade was primarily taking place in taverns such as the ones in Skadarlija quarter. Many pieces of art were also created there, making this part of the city known as a unique ambience that keeps telling the story of urban Belgrade culture to this date. In this paper, a brief history of Skadarlija and the artistic actions that revived the quarter since late 1960s allowing its positioning as a tourist attraction, provide the frame for discussing conceptualization of Belgrade as a city at play.
\end{abstract}

Key words: Skadarlija, taverns, bohemians, artistic action, tourist atraction, city at play

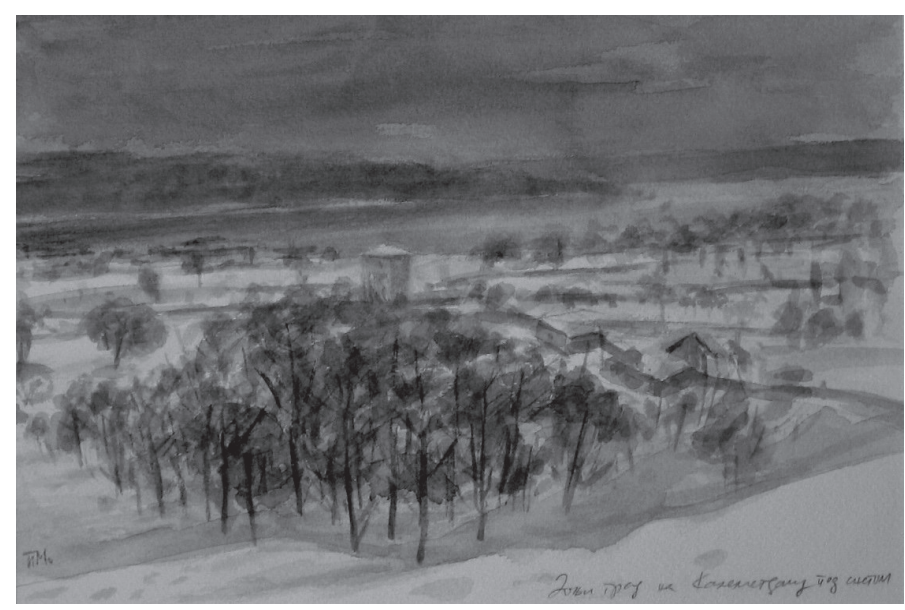

Миле В. Пајић, Доњи град под снегом, Београд 